The Review of Finance and Banking

Volume 13, Issue 2, Year 2021

http://dx.doi.org/10.24818/rfb.21.13.02.03, Pages 121-133

S print ISSN 2067-2713, online ISSN 2067-3825

\title{
COMMITMENT TO CAPITAL RAISING FOR VENTURE CAPITAL FUNDS IN INDIA: AN APPLICATION OF ARDL MODEL
}

\author{
MOHAMMAD MUSTAFA AND SYED SHAHID MAZHAR
}

\begin{abstract}
Venture capitalists (VCs) flourish on the ability to add funds to their kitty across nations. Consequently, VCs' ability to convince Limited Partners (LP), who are their primary source of financing, plays a critical role in the venture capital investment growth in any economy. However, it is not easy to rake in capital from an investor. LPs assess the market conditions carefully before making their capital available to the VCs. This paper examines the macro-economic variables that influence the supply of money to venture capital funds in emerging economies such as India from an LPs perspective. The empirical analysis using Autoregressive-Distributed Lag (ARDL) approach reveals that supply of capital to the VC funds in India is influenced by macro variables as well as past investment behaviours. Macro-variables such as GDP growth, interest rate spread, global liquidity, and inflation rate significantly influence the supply of capital to the VC funds in India. However, stock market liquidity does not influence the supply side of the venture capital investment. Our analysis reveals that VCs' fund raising in India is highly influenced by their past investment relation with the LPs.
\end{abstract}

\section{INTRODUCTION}

With the advent of liberal market policies in 1991, India opened many industries and sectors to foreign investment. As a result, the overseas capital inflow has increasingly exploited an underfunded market, Mustafa (2019). The Indian venture capital industry is a thriving testimony of the same. We must mark that around 70 percent of venture capital investment in India comes from the external market. Consequently, the Indian venture capital industry has evolved substantially during recent years, basking in the prosperity of foreign money. In the venture capital industry, fundraising by the firms has reached 117 billion rupess by the end of 2020. However, the total fundraised is low compared to the 268 billion rupees commitment made by the LP investors. It is to be noted that the total fund received by the Indian VC firms stands at around 45 percent of the commitment made by investors to the industry. In 2016 the total investment was just 20 percent of the entire corpus committed by the investors (as shown in Figure -1 of Appendix A) ${ }^{1}$. However, over the last four years, the growth of capital raising capacity by Indian VC firms has outstripped the increase in the commitment made by the investors to the fund managers. As a result, the sector is witnessing marginal improvement in recent quarters.

Received by the editors June 1, 2021. Accepted by the editors November 1, 2021.

Keywords: VC, Commitment, Capital, LP, Liquidity.

JEL Classification: ???

Mohammad Mustafa, PhD Candidate, Principal Secretary Public Enterprises, Ex- Chairman \& Managing Director, Small Industries Development Bank of India, New Delhi, India. E-mail: md.mustafa.research@outlook.com.

Syed Shahid Mazhar, PhD, Associate Professor and Head, Department of Commerce \& Business Management Integral University, Lucknow, India. E-mail: shahid.dphil@gmail.com.

This paper is in final form and no version of it will be submitted for publication elsewhere.

${ }^{1}$ The ratio has sharply increased to $54 \%$ in March 2015 and then came down to $16 \%$ in June 2016 . We note here that pension funds are allowed to invest in VC industry in 2016. During the same year, Insolvency and Bankruptcy Code was also implemented. 
Limited Partners plays a critical role in the growth of VC funds. In the venture capitalist's investment ecosystem, VC funds act as intermediaries, pooling capital from various sources (known as LP) and investing in start-ups or early-stage entities. Venture capital investment in a country will flourish if it can raise higher funds. Limited partners are the foundation of this ecosystem, providing funds to the VC firms and setting the course of venture capital investment's growth. Further, if the supply of funds to the VC firms is limited, the financial intermediary will find it difficult to provide financial support to the portfolio companies (Lin and Varottil, 2019). As discussed above, LPs invest significantly less than what they commit to the fund managers. Therefore, it is essential to understand what factors motivate the investors to supply more capital to the VC funds focused on a given country from the supply-side perspective. This will increase the liquidity with the VC funds and thereby increase their ability to finance a higher number of start-ups.

In literature, various factors that motivate the Indian $\mathrm{VC}$ firms to invest have been widely discussed. However, what determines the supply of funds to the VC firms has been overlooked. A study on the supply side of the $\mathrm{VC}$ fund is essential for understanding and promoting this investment in India, where the availability of capital specifically for small enterprises is scarce. Therefore, this paper intends to examine the supply of funds to the VC firms in three steps. First, factors that entice the investors (LPs) to commit money to the VC firms willingly. Second, factors that attract the LPs to invest in the VC funds focused on an economy. Finally, examining the factors that will hasten the growth of funds supplied to the VC firms over commitment made to them.

The rest of the paper is organized in the following order. Section 2 reviews the association between venture capital investment and macroeconomic variables. Section 3 presents the methodology for empirical analysis. Section 4 discusses empirical results and Section 5 concludes this study.

\section{REView of Literature}

The determinant of venture capital investment has long been an important research topic in the alternative investment literature. While examining the factors determining the supply of VC funds in the US, Gomper and Larner (1998) used industry aggregate data from 1969 to 1994. The study used net venture capital investment in an absolute term in a fixed-effect model. It explored and established that economic growth, firm-specific performance, and capital gain tax are the critical factors influencing the supply of VC funds. The authors believed that the recent return of firms could lead to higher commitment. Though the authors claimed that capital gain tax is the driving force for venture capital investment, Balboa and Marti (2001) later revealed that capital gain tax influences only the tax-sensitive investors. Further, examining the demand and supply of the venture capital investment, Cannice and Goldberg (2009) argued that the ability to invest by the $\mathrm{VC}$ funds is determined from the level of commitment of the investors.

Another study by Gomper et al. (1998) observed that a favourable IPO market could determine the availability of funds for venture capital investment. Further, the willingness of investors to commit money is driven by the expectation of return from the $\mathrm{VC}$ investment. Black and Gilson (1998) also observed a strong nexus between venture capital market and robust capital market during the same period. They argue that a resilient IPO market with good returns can encourage the venture capital market from both the demand and supply sides. Further reinforcing the argument, Jeng and Wells (2000) cited that exit through IPO is the most profitable option for a venture capitalist. Therefore, the volume of IPOs can affect both the supply and demand of venture capital.

Balboa and Marti (2001) tried to examine the determinants of venture capital investment in the European region. The authors considered that countries' information asymmetric is high. The result revealed that GDP growth does not influence the flow of venture capital investment. If we go by the findings of Jeng and Wells (2000), it suggests that healthy growth in the number of IPOs indicates money is going back to the investors. Hence, it can be assumed 
that the expected return from the portfolio was lucrative. However, market capitalization or the active stock market does not seem to influence the early-stage investment. Schertler (2003) used stock market capitalization as a proxy for stock market liquidity to examine the factors that influence venture capital investment. The author cited that stock market liquidity can positively impact venture capital investment at an early stage.

Fleix et al. (2007) employed panel regression from 1992 to 2003 for 23 European countries. The authors attempted to explore the factors determining the supply and demand of venture capital investment in the European region. The study builds a separate model and assesses the supply-side and demand-side factors. Their analysis reveals that market capitalization and interest rate are strong determinants of $\mathrm{VC}$ investment in the European region. They believe that a positive association between $\mathrm{VC}$ investment and interest rate implies that demand for such investment increases when the cost of capital remains high in the market. However, in the case of GDP growth, unlike the finding of Gomper and Larner (1998), this study finds this variable is not essential for the $\mathrm{VC}$ investment in the EU region.

Even Chief and Gazdar (2011) employed panel regression to identify the factors influencing venture capital investment across 21 European countries. Their result explored that GDP growth, market capitalization and expenditure on $\mathrm{R} \& \mathrm{D}$ are the decisive determinants of venture capital investment in the European region. Romain and Pottelsberghe (2004) tried to explore the role of macroeconomic variables on venture capital investment considering 16 Organisation for Economic Co-operation and Development (OECD) countries for 1990 to 2000. Their work reveals that venture capital investment is positively associated with GDP growth and interest rate.

Bonini and Alkan (2011) reveal macro-variables such as interest rate, GDP growth, inflation rate, and stock market liquidity are the motivational factors for venture capital investment. However, the influence of GDP growth on venture capital is limited to the early stage only. Considering quarterly data for 17 years between 1995 and 2011, Ning et al. (2015) attempted to explore the driving forces of venture capital investment in the US. The study reveals that GDP growth and change in IPO are the vital drivers of the VC investment in the US.

Neeraz and Tripathi (2019) attempted to examine the factors determining alternative investment categories, including venture capital, in India's sector-level analysis. The study used principal component analysis for examining the relationship between macro-variables and alternative investment. This study's finding pertaining to the impact of macro-variables was inconclusive as their effects vary from sector to sector.

While examining the demand side of the VC funds, Mustafa and Mazhar (2020) revealed that venture capital investment is strongly influenced by domestic factors such as GDP growth, stock market liquidity and inflation rate. In addition to the domestic factor, global factors also influence the rate of venture capital investment in developing countries like India.

Based on the earlier studies, it can be inferred that macro-economic variables such as GDP growth, stock market liquidity, inflation rate, liquidity in the global financial system and interest rate are the influential factors for venture capital investment. It was observed that the past studies conducted on the emerging markets had examined the major influential factors for venture capital investments on the demand side only. That is how VC funds invest in an economy. However, most literature pertaining to the subject has overlooked the supply side of the VC funds - what influences the VC funds' fundraising. In emerging economies, the availability of capital is a major concern. Therefore, examining the driving factors of the supply of capital to the VC funds is very important.

Further, foreign investors are the major contributor in the emerging market venture capital industry, evidenced in India. Therefore, determinants of venture capital investment in emerging markets like India should be measured considering the relative performance of the economy. In this context, Verma and Prakash (2011) examined the sensitivity of capital flows to interest rate differential in India. The authors used a 10-year yield spread between India and the US to proxy for interest rate spread. They concluded that a 1.0 percent change in interest rate 
differential could lead to a 0.05 percent change in the capital inflows in the same direction. Before this, the work of Chakravorty (2006), Singh (2007) and Singh (2009) revealed that interest rate differential is a strong determinant of capital inflows to emerging markets. Therefore, it is appropriate to consider interest rate differential as an explanatory variable instead of the prevailing interest rate in the domestic market.

\section{Methodology}

This paper has considered the data available on venture capital investments for the fiscal quarters starting December 2012 till December 2020 to carry out a series analysis. The data on quarterly frequency has been collected from the Securities and Exchange Board of India, Reserve Bank of India, Centre for Monitoring Indian Economy (CMIE), and Federal Reserve Bank of St. Louis. Data of capital received by various VC funds and the wealth committed to the VC fund pool by different investors (LPs) is taken from SEBI. The committed capital is the amount investors have promised to invest into the VC funds. Similarly, capital raised is the total money received by different VC funds from investors. The capital received by the VC funds could be concurrent with the changing level of commitment of the investors. Therefore, we aimed to examine the influence of macroeconomic variables on the ratio of capital received by the VC funds to the commitment made by the investors.

The independent variables considered in the models are GDP growth, Interest rate spread, stock market liquidity, global liquidity, and inflation rate. For interest-rate differential, spread between the 10-year sovereign yield of India and the US has been considered. Similarly, change in the Federal Reserve's asset side has been considered a proxy for global liquidity.

3.1. Independent variables. GDP growth: GDP growth reflects the health of the economy. Therefore, healthy GDP growth encourages higher venture capital investments. At the same time, new start-up firms will emerge when an economy is expanding rapidly. Hence, higher demand for venture capital investment is expected. The earlier studies conducted by Gomper and Larner (1998), Fleix et al. (2007), Chief and Gazdar (2011), Ning et al. (2015), Mustafa and Mazhar (2020) have considered GDP growth as a significant explanatory variable of venture capital investment. On the supply side, faster economic expansion will create greater business opportunities. Therefore, considering growing investment opportunities, investors are expected to pour more money into the $\mathrm{VC}$ funds of an economy when that economy experiences faster growth. Furthermore, during such times, actual money invested to money committed rises as investors are confident about better returns (IRR).

Interest rate spread: Global capital inflows to the emerging market remain high when the interest rate differential between emerging and advanced economies is higher. Investment in the emerging market can fetch a higher return. Therefore, the supply of capital towards venture capital can increase in a country that offers a higher return (because of higher interest rates). Investment in VCs is part of the portfolio management exercise undertaken by respective family offices of LPs. While the subject of capital allocation among segments is not a concern for this paper, $\mathrm{VC}$ segment in LP capital allocation is considered significant because of potential returns. Further, a higher interest rate can nudge an enterprise towards exploring alternative funding sources as borrowing from the bank becomes expensive. Therefore, actual venture capital investment is expected to increase from both the demand and supply sides. Among the earlier studies, Gomer et al. (1998), Romain and Pottelsberghe (2004), Fleix et al. (2007) have considered domestic interest rate as an explanatory variable. Fleix et al. (2007) argue that a positive association between $\mathrm{VC}$ investment and interest rate implies that demand for such investment increases when the cost of capital remains high in the market.

Stock market liquidity: Exit through IPO can optimize the return from venture capital investment. Therefore, the liquid stock market can encourage higher supply to the venture capital industry from an investor perspective. Similarly, a liquid stock market can facilitate an opportunity for the entrepreneur to take back or enhance its control over the entity. Bonini and 
Alkan (2011) argue that number of IPOs is an outcome of venture capital investment. Hence, venture capital investment leads IPO not the reverse. Therefore, earlier studies such as Jeng and Well (2000), Schertler (2003), Romain and Pottelsberghe (2004), Bonini and Alkan (2011) Mustafa and Mazhar (2020) considered stock traded as a proxy for stock market liquidity.

Global Liquidity: When the global financial market has excess money, higher capital inflows to EME (emerging market economies) are generally yield chasing as interest rate differentials become more pronounced. Consequently, supply of capital to the VC firms in expectation of higher return will be higher when global financial system is having surplus liquidity. Therefore, Mustafa and Mazhar (2020) have considered this variable as a potential explanatory variable.

Inflation rate: Firm inflation rate reflects the level of consumer demand in an economy. Hence, higher investment is expected when rate of inflation is strong. As a result, demand for funds from fund manager would be firm as well. On the supply side, higher consumer demand in an economy can give confidence to the investors about the investee economy. In literature, Bonini and Alkan (2011) and Mustafa and Mazhar (2020) has explored a positive impact of price level on overall VC investment.

To explore the existence of cointegration relationship among the variable bounds testing approach in the framework of Autoregressive Distributed Lag (ARDL) (as developed by Pesaran et al. 2001) has been employed. The cointegration approach developed by Pesaran et al. (2001) has some econometrics advantages (Durairaj, 2010) compared to other cointegration procedures. For instance, the bounds test approach can be applicable for a small sample size study (Pesaran et al., 2001; Udoh et al, 2015), whereas another conventional multivariate cointegration approach such as Johansen and Juselius approach is effective only for large sample size. Further, the estimates of the long-run model provided by the test will be unbiased despite some regressors are endogenous (Harris and Sollis, 2003; Udoh et al, 2015). Therefore, in this paper, we have applied the ARDL model.

The ARDL procedure includes two stages. In the first stage, it identifies the presence of a long-run association among the variables. Once the long-run association is established, in the next step, it estimates the long-run relationship. A simple ARDL model can be presented as follows:

$$
\begin{aligned}
Y_{t}= & \alpha_{0}+\sum_{i=1}^{p} \delta_{1} Y_{t-i}+\sum_{j=0}^{q 1} \delta_{2} G D P_{t-j}+\sum_{k=0}^{q 2} \delta_{3} \text { Spread }_{t-k}+ \\
& \sum_{l=0}^{q 3} \delta_{4} S M L_{t-l}+\sum_{m=0}^{q 4} \delta_{5} G L_{t-m}+\sum_{n=0}^{q 5} \delta_{6} C P I_{t-n}+\epsilon_{t}
\end{aligned}
$$

Where, $\alpha_{0}$ is the constant, $\delta_{i}$ are the long-run multiplier, and $\epsilon_{t}$ are white noise errors.

$$
\begin{aligned}
\triangle Y_{t}= & \gamma+\sum_{i=1}^{p} \partial_{1} Y_{t-i}+\sum_{j=0}^{q 1} \partial_{2} G D P_{t-j}+\sum_{k=0}^{q 2} \partial_{3} \text { Spread }_{t-k}+ \\
& \sum_{l=0}^{q 3} \partial_{4} S M L_{t-l}+\sum_{m=0}^{q 4} \partial_{5} G L_{t-m}+\sum_{n=0}^{q 5} \partial_{6} S M L_{t-n}+\theta e c m_{t-1}+\epsilon_{t}
\end{aligned}
$$

Where $\mathrm{Y}$ is a dependent variable, $\gamma$ is the constant, $\partial_{i}$ are the short-run dynamic coefficients of the model's convergence to equilibrium, $\theta$ is the speed of adjustment, and $\epsilon_{t}$ are white noise errors. 


\begin{tabular}{|l|l|l|c|}
\hline \multicolumn{1}{|c|}{ Variable } & \multicolumn{1}{|c|}{ Description } & Notation & Predicted sign \\
\hline Committed Amount & $\begin{array}{l}\text { Limited Partners promise to invest } \\
\text { in the venture capital fund }\end{array}$ & CA \\
\hline Capital Received & $\begin{array}{l}\text { The amount received by VC funds } \\
\text { from the LPs }\end{array}$ & CR & $\#$ \\
\hline $\begin{array}{l}\text { Capital received to the } \\
\text { committed amount ratio }\end{array}$ & $\begin{array}{l}\text { The ratio of capital received and } \\
\text { committed amount }\end{array}$ & CRTC & $\#$ \\
\hline GDP growth & Inflation-adjusted quarterly output & GDP & + \\
\hline Interest rate differential & $\begin{array}{l}\text { Spread between 10-year Indian and } \\
\text { US sovereign yield }\end{array}$ & Spread & + \\
\hline Stock Market Liquidity & The stock traded to GDP ratio & SML & + \\
\hline Global Liquidity & $\begin{array}{l}\text { Change in the asset side of the Fed's } \\
\text { balance sheet }\end{array}$ & GL & + \\
\hline Inflation rate & Growth in the consumer price index & CPI & + \\
\hline \multicolumn{2}{|l|}{ Note: $\#$ is the dependent variable } \\
\hline
\end{tabular}

\section{Empirical Analysis}

This paper aims to examine how the macroeconomics variables influence the commitment and actual investment of the LPs into the Indian VC funds. This paper has used the autoregressive distributed lag (ARDL) approach to examine the relationship empirically. As macroeconomics variables have a dynamic relationship, examining with time series econometrics models like the ARDL model is more appropriate.

4.1. Unit root test. The result of the unit root test applying the Augmented Dickey-Fuller (ADF) approach for the variables CA, CR, CRTC (capital received to committed amount ratio), GDP growth, Spread, SML, GL, and CPI is presented in Table 1. The ADF test result reveals that all the variables are stationary at the first difference (at $1 \%$ level), i.e., is integrated of order one, (I). As the considered variable for the ARDL model is stationary at the first difference, a long-run equilibrium relationship can be examined by applying the bounds test.

\begin{tabular}{|l|c|c|}
\hline \multicolumn{3}{|c|}{ Table 1: Unit Root Tests } \\
\hline Variables & Level (0) & First Difference (I) \\
\hline CA & 0.867 & $-3.597^{*}$ \\
\hline CR & 1.897 & $-3.194^{*}$ \\
\hline CRTC & -0.231 & $-3.118^{*}$ \\
\hline GDP & -1.174 & $-5.782^{*}$ \\
\hline Spread & -0.639 & $-4.403^{*}$ \\
\hline SML & 0.521 & $-4.619^{*}$ \\
\hline GL & 0.741 & $-5.685^{*}$ \\
\hline CPI & 1.441 & $-3.815^{*}$ \\
\hline Note: $*$ indicates significance at $1 \%$ level \\
\hline
\end{tabular}

4.2. Bounds test. Before proceeding with the bounds test, the order of lags on the first differenced variables has been examined using AIC. In the next step, an F-statistic test was conducted to examine the long-run relationship among the considered variables. The F-statistic of bounds test is higher than the upper bound critical value at the 5 percent level. This infers that the variables considered for the assessment are having long-run cointegration ${ }^{2}$.

\footnotetext{
${ }^{2}$ The null hypothesis of the null hypothesis of no cointegration among the macro variables can be rejected as F-statistic value is greater than the upper bound of the critical value. If the estimated value remains below the lower bound of the critical value, the null hypothesis of no cointegration among the macro variables cannot be rejected. Similarly, it cannot be judged if it remains within the lower and upper bound.
} 


\begin{tabular}{|l|c|c|}
\hline \multicolumn{3}{|c|}{ Table 2: F-Bounds test for Cointegration Relationship } \\
\hline Number of regressors & Value of statistics $\mathrm{k}=5$ \\
\hline Model & $\mathrm{M} 1$ & $\mathrm{M} 2$ \\
\hline Computed F- statistic & 5.124 & 5.159 \\
\hline Critical value & At $1 \%$ level & At $5 \%$ level \\
\hline Lower bound value & 4.257 & 3.037 \\
\hline Upper bound value & 6.040 & 4.443 \\
\hline \multicolumn{3}{|c|}{ Note: $\mathrm{k}$ is the number of regressors } \\
\hline
\end{tabular}

4.3. Error Correction Model. The equation (1) was estimated after following the findings of a long-run cointegration among the considered variables. The result of the ARDL model is presented in Table 3. In Model 1, the variables GDP growth, GL, CPI, and spread have a longrun association with the dependent variables as the coefficient of these variables is statistically significant. The coefficient of the variables of GDP growth, CPI, and GL are significant at 5 percent level or above with positive sign, whereas coefficient of spread is significant at 10 percent only. The GDP growth and CPI signify healthy economic outlook and strong consumer demand which is good for investment in domestic economy. Therefore, dependent variable is positively influenced by these variables. In the earlier study, Gomper et al. (1998) also stated that investors promise to invest more on the VC funds when expected rate of return is higher. Similarly, significance of the coefficient of the variable GL and Spread with positive sign implies that surplus liquidity in the global financial system motivates the investors to take advantage of the relatively higher rate of interest in the domestic market.

Similar to the result of Model 1, the variable GDP growth, GL, CPI, and spread are found to be significant in Model 2 as well. The coefficient of the GDP growth, CPI, and GL is significant at a 5 percent level or above, whereas the spread is significant at 10 percent only. A positive sign of the coefficient of all these variables indicates a positive association between the independent variables and fundraising. On the demand side of the analysis by Mustafa and Mazhar (2020), GDP growth, CPI, GL, and SML are the influential factors. However, stock market liquidity is not found to be significant on the supply side. As the share of exit through IPO is very low in India (Mustafa, 2019), stock market liquidity does not influence the supply of capital to the $\mathrm{VC}$ funds in India.

\begin{tabular}{|l|c|c|}
\hline \multicolumn{3}{|c|}{ Table 3: Long run coefficients using ARDL approach } \\
\hline Independent Variables & \multicolumn{2}{c|}{ Dependent Variable } \\
\hline & $\mathrm{CA}_{t}(1)$ & $\mathrm{CR}_{t}(2)$ \\
\hline \multicolumn{1}{|c|}{ ARDL } & $(1,1,2,1,2,1)$ & $(1,2,0,0,0,1)$ \\
\hline CA & $0.146(0.616)$ & $0.7099(16.453)^{* * *}$ \\
\hline CR & $0.012(4.210)^{* * *}$ & $0.003(3.031)^{* * *}$ \\
\hline GDP & $0.004(1.797)^{*}$ & $0.005(1.816)^{*}$ \\
\hline Spread & $-0.001(-0.971)$ & $-0.001(-0.897)$ \\
\hline SML & $0.0098(2.815)^{* *}$ & $0.005(4.380)^{* * *}$ \\
\hline GL & $0.0032(3.926)^{* * *}$ & $0.0030(4.731)^{* * *}$ \\
\hline CPI & $-0.302(-3.40)^{* * *}$ & $-0.0006(-0.135)$ \\
\hline Constant & Note: ${ }^{*},{ }^{* *},{ }^{* *}$ indicates significance at \\
\hline \multicolumn{3}{|c|}{10,5 and $1 \%$ level respectively. } \\
\hline
\end{tabular}

It was observed that as compared to that of the CR, CA is highly elastic to the GDP growth and global liquidity. Likewise, CR is highly elastic to the change in interest rate spread as compared to the variable CA. Our analysis reveals that a 10bps change in interest rate spread can lead to INR 0.04 million change in committed amount and INR 0.05 million change in capital receipt on the same direction. It can be inferred that interest rate spread induce capital receipts more than its commitment. Therefore, higher interest rate spread can narrow down the gap between committed amount and actual capital receipts. Further, CR is strongly influenced 
by its own lag. This implies that a fund managers ability to raise capital may be influenced by his/her investment relationship with the LPs along with their past performances. In an assessment in the EU region, Balboa and Marti (2001) also observed that raising new funds is significantly influenced by the past performance of the fund managers.

In another model, we have considered a ratio of capital receipts and committed amount as a dependent variable and had run a regression. However, the result is contradictory, therefore, we are not reporting the result here.

\begin{tabular}{|c|c|c|}
\hline \multirow{2}{*}{\multicolumn{3}{|c|}{$\begin{array}{c}\text { Table 4: Estimated Coefficients of the Sho } \\
\text { Dynamic Error Correction Model }\end{array}$}} \\
\hline & & \\
\hline Independent Variables & \multicolumn{2}{|c|}{ Dependent Variable } \\
\hline & $\Delta \mathrm{CA}_{t}(1)$ & $\Delta \mathrm{CR}_{t}(2)$ \\
\hline Constant & $-0.312(-6.522)$ & $-12.394(-6.303)$ \\
\hline $\mathrm{ECM}_{t-1}$ & $-0.882(-6.525)^{* * *}$ & $-0.273(-6.374)^{* * *}$ \\
\hline $\mathrm{GDP}_{t-1}$ & $0.001(0.662)$ & $1.422(9.641)^{* * *}$ \\
\hline $\mathrm{GDP}_{t-2}$ & - & $-0.824(-3.593) * * *$ \\
\hline Spread $_{t-1}$ & $-0.0004(-1.943)^{*}$ & - \\
\hline Spread $_{t-2}$ & $-0.0004(-2.425)^{* *}$ & - \\
\hline $\mathrm{SML}_{t-1}$ & $0.005(4.241)^{* * *}$ & - \\
\hline $\mathrm{GL}_{t-1}$ & $-0.003(-2.557)^{* *}$ & - \\
\hline $\mathrm{GL}_{t-2}$ & $-0.003524(-2.557)$ & - \\
\hline $\mathrm{CPI}_{t-1}$ & $0.0003(5.939)^{* * *}$ & $-0.015(-2.785) * * *$ \\
\hline $\mathrm{CA}_{t-1}$ & $0.0688(0.378)$ & - \\
\hline $\mathrm{CR}_{t-1}$ & - & $-0.379(-3.074)^{* * *}$ \\
\hline \multicolumn{3}{|c|}{ Note: $* * *, * * \& *$ indicates significance at } \\
\hline 1 percent, 5 percen & and 10 percent les & el respectively. \\
\hline
\end{tabular}

The findings of the short-run dynamic associated with the long-run behaviour have been obtained from the error correction model as presented in Table 4. For the first model, the coefficient (-0.88) of the error correction model is significant at a 1percent level with the correct sign. This suggests that the speed of adjustment in the dependent variable to any shock is strong. Approximately 88 percent of disequilibrium from a shock in a period can return to the long-run equilibrium in the next period. However, in the case of model 2, the speed of adjustment in the dependent variable to any shock is only 27 percent during a period.

\begin{tabular}{|l|c|c|}
\hline & Model 1 & Model 2 \\
\hline R-squared & 0.9972 & 0.976 \\
\hline Adj. R-squared & 0.9961 & 0.965 \\
\hline F- statistic & $11.95^{* * *}$ & $94.72^{* * *}$ \\
\hline Akaike info criterion & -411.13 & -533.90 \\
\hline LM Test for residual correlation & $0.353(0.563)$ & $0.868(0.356)$ \\
\hline Test for normality & $0.956(0.237)$ & $0.974(0.658)$ \\
\hline Test for heteroscedasticity & $22.235(0.176)$ & $7.205(0.926)$ \\
\hline
\end{tabular}

Further, the stability of the model has been checked with the behaviour of the recursive residual. The graphical representation of CUSUM (Cumulative Sum of Recursive Residuals) and CUSUMSQ (Cumulative Sum Square of Recursive Residual) in Figure 2 in Appendix A are applied to the ECM model suggested by the AIC criterion. In the figures, the recursive residual remains within the critical bounds. Based on the plot, we can conclude that the estimated model has no evidence of instability.

\section{Conclusion}

In the past, many theoretical and empirical studies have attempted to examine the key determinants of venture capital investment. However, on the supply side, a study on capital-raised 
by VC funds compared to LP commitment can explore investor strategy. This assessment is pivotal to emerging markets like India, where the availability of capital is limited. Consequently, the cost of capital remains elevated for small enterprises.

This paper explores the supply of investment (capital) in India through the conduits built by VCs. In this regard, this study used quarterly data from December 2012 to December 2020. An ARDL model was applied to explore the influence of the macro variables such as GDP growth, Interest rate spread, Stock market liquidity, global liquidity, and inflation rate.

Further, this study explored the factors that motivate the investors to supply more capital to the VC funds than what they have committed. The empirical analysis reveals that supply of capital to the VC funds in India is influenced by macro variables as well as past investment behaviours. Macro-variables such as GDP growth, interest rate spread, global liquidity, and inflation rate significantly influence the supply of capital to the VC funds in India. However, influence of stock market liquidity is found to be insignificant on the supply side of the venture capital investment.

In case of interest rate spread, our empirical analysis reveals that a higher interest rate in host economy as compared to the global rate of interest can encourage LPs to pour more money into the VC funds compared to what they committed. As a result, the gap between the actual supply of funds and the promise to invest will come down. Further, the actual capital investment is highly influenced by its past behaviour. This implies that LPs puts money into the $\mathrm{VC}$ funds based on the past investment relation with the fund managers.

Concluding, the capital received by the $\mathrm{VC}$ funds in India is around 45 percent of the investors' commitment to the industry. This study has explored that a lucrative domestic economic outlook can improve the domestic VC funds' fundraising capability (higher capital raised to commitment ratio). Our analysis suggests that it is a good time to raise funds during surplus global liquidity and higher interest rate spreads, however, fund managers need to have a good track record to give confidence to the LPs.

This is an early attempt to explore macroeconomic variables' influence on committed amounts and capital-raised by the VC funds. We have limited our analysis to macro level as our aim is to examine the supply of capital influenced by the macroeconomic variables in general. Therefore, we admit that our findings should be interpreted cautiously. However, a further study considering industries and geographical areas can give more clarity on this relationship. In addition, while we acknowledge that the tax and legal system in the host economy also influence international capital movement, we could not include these factors due to limited observations. Therefore, a further study incorporating these parameters will enrich this finding.

\section{REFERENCES}

[1] Balboa, Marina and Jose Marti. 2001. "The determinants of private equity fundraising in western Europe." EFMA Working Papers. DOI: doi.org/10.2139/ssrn.269789.

[2] Black, Bernard and Ronald Gilson. 1997. "Venture capital and the structure of capital markets banks versus stock markets." Journal of Financial Economics 47, no.3: 243-277. doi.org/10.1016/S0304-405X(97)00045-7.

[3] Bonini, Stefano and Senem Alkan. 2011. "The Political and Legal Determinants of Venture Capital Investments around the World", Retrieved from https://ssrn.com/abstract $=945312$.

[4] Cannice, Mark and Cathy Goldberg. 2009. "Venture capitalists' confidence, capital commitments, and capital investments." Int. J. Techno entrepreneurship 2, no.1: 79-98. Retrieved from https://repository.usfca.edu/cgi/viewcontent.cgi?article=1027\&context=esib.

[5] Cherif, Mondher, and Kaouthar Gazdar. 2011. "What drives venture capital investments in Europe? New results from a panel data analysis." Journal of Applied Business and Economics 12, no.3: 122-139.

[6] Durairaj, Kumarasamy. 2010. "Foreign direct investment, Export, and Economic growth in India: An application of ARDL model." Asian African Journal of Economics and Econometrics 10, no. 2: 245-259. Retrieved from https://ssrn.com/abstract $=2259234$.

[7] Fleix, Elisabete, Mohamed A. Gulamhussen and Cesaltina P. Pires. 2007. "The determinants of venture capital in Europe - Evidence across countries." CEFAGE-UE Working Paper 2007/01. Retrieved from Centre for Advanced Studies in Management and economics website: http://www.cefage.uevora.pt/en/producao_cientifica/working_papers_serie_cefage/the_determinants_ of_venture_capital_in_europe_evidence_across_countries. 
[8] Gompers, Paul, and Josh Lerner. 1998. "Venture capital distributions: short and long-run reactions." Journal of Finance 53, no.6: 2161-2183. http://www.jstor.org/stable/117464.

[9] Gompers, Paul, Josh Lerner, Margaret Blair, and Thomas Hellmann. 1998. "What Drives Venture Capital Fundraising?" Brookings Papers on Economic Activity. Microeconomics 1998, no. 1998: 149-204. doi: $10.2307 / 2534802$.

[10] Groh, Alexander and Heinrich Liechtenstein. 2012. "Assessing Country Attractiveness in the Venture Capital and Private Equity Landscape in Emerging Markets." doi.org/10.2139/ssrn.2021987.

[11] Groh, Alexander and Johannes Wallmeroth. 2016. "Determinants of venture capital investments in emerging markets." Emerging Market Review 29: 104-132. https://doi.org/10.1016/j.ememar.2016.08.020.

[12] Jeng, Leslie and Philippe Wells. 2000. "The determinants of venture capital funding: evidence across countries." Journal of Corporate Finance 6, no.3: 214-289. doi.org/10.1016/S0929-1199(00)00003-1.

[13] Kim, Jae and In Choi. 2017. "Unit root in economic and financial time series: A re-evaluation at the decision-based significant levels." Econometrics 5, no.41: 1-23. doi.org/10.3390/econometrics5030041.

[14] Kortum, Samuel and Josh Lerner. 2000. "Assessing the contribution of venture capital to innovation." The Rand Journal of Economics 31, no.4: 674-692. doi.org/10.2307/2696354.

[15] Lin, Lin and Umakanth Varottil. 2019. "Venture Capital in China and India: Does Business Form Matter?" NUS Centre for Legal Studies Working Paper 2019/017. Retrieved from: http://dx.doi.org/10.2139/ssrn.3451627.

[16] Manigart, Sophie and Christof Beuselinck. 2001. "Supply of venture capital by European government.' Faculteit Economie, University Gent Working Paper No. 2001/111. Retrieved at: http://citeseerx.ist.psu.edu/viewdoc/download?doi=10.1.1.199.5020\&rep=rep1\&type=pdf.

[17] Mustafa, Mohammad and Syed S. Mazhar. 2020. "Determinants of venture capital investment in India: A time series analysis." The Review of Finance and Banking 12, no.1: 19-30. Retrieved at http:// d x.doi.org/10.24818/ r fb.20.12.01.02.

[18] Mustafa, Mohammad. 2019. "Overview of Venture Capital Landscape in India." The Journal of Private Equity 23, no.1: 63-89. DOI: 10.3905/jpe.2019.1.098.

[19] Neerza, Neerza and Vanita Tripathi. 2019. "Determinants of private equity investment across sectors in India." Journal of Advances in Management Research 16, no.4: 513-536. DOI: doi.org/10.1108/JAMR-092018-0083.

[20] Ning, Yixi, Wei Wang, Bo Yu. 2015. "The driving forces of venture capital investments." Small Business Economics 44, no. 2: 315-344. DOI: 10.1007/s11187-014-9582-4.

[21] Nuthalapati, S. Chandra and Kartikeya Singh. 2019. Venture capital technology and innovative start-up in India, Tech Monitor, 20-27.

[22] Pesaran, Hashem, Yongcheol Shin and Richard Smith. 2001. "Bounds Testing Approaches to the Analysis of Level Relationships." Journal of Applied Econometrics 16, no. 3: 289-326. Retrieved from https://doi.org/10.1002/jae.616.

[23] Pradhan, Rudra, Mak B. Arvin, Mahendhiran Nair, Sara E. Bennett and Sahar Bahmani. 2019. "Short-term and long-term dynamics of venture capital and economic growth in a digital economy: A study of European countries." Technology in Society 57, no.5: 125-134. DOI: https://doi.org/10.1016/j.techsoc.2018.11.002.

[24] Romain, Astrid and Bruno Van Pottelsberghe. 2003. "The determinants of venture capital: A panel data analysis of 16 OECD countries." IIR WP 03-25. Hitotsubashi University. Retrieved from: https://core.ac.uk/download/pdf/6451443.pdf.

[25] Schertler, Andrea. 2003. "Driving forces of venture capital investments in Europe: A dynamic panel data analysis." Kiel working paper 1172. Kiel Institute for World Economics, Kiel. Retrieved from: http://hdl.handle.net/10419/17695.

[26] Singh, Bhupal. 2007. "Corporate Choice for Overseas Borrowings: The Indian Evidence", RBI Occasional Papers, Reserve Bank of India 28, no.3: 1-33. Retrieved from https://mpra.ub.uni-muenchen.de/13220.

[27] Singh, Bhupal. 2009. "Changing Contours of Capital Flows to India." Economic and Political Weekly 44, no.43. Retrieved from: https://www.epw.in/journal/2009/43/special-articles/changing-contours-capitalflows-india.html.

[28] Udoh, Elijah, Udoma Afangideh and Udeaja A. Elias. 2015. "Fiscal decentralization, economic growth and human resource development in Nigeria: Autoregressive Distributed Lag (ARDL) approach." CBN Journal of Applied Statistics 6, no.1: 69-93. Retrieved from http://hdl.handle.net/10419/142091.

[29] Verma, Radheshyam and Anand Prakash. 2011. "Sensitivity of Capital Flows to Interest Rate Differentials: An Empirical Assessment for India." RBI working paper 07, Reserve Bank of India. Retrieved at https://m.rbi.org.in/Scripts/PublicationsView.aspx?id=13364. 
Appendix A

Figure 1: Ratio of capital raised and commitment (from LPs) to Indian VC funds

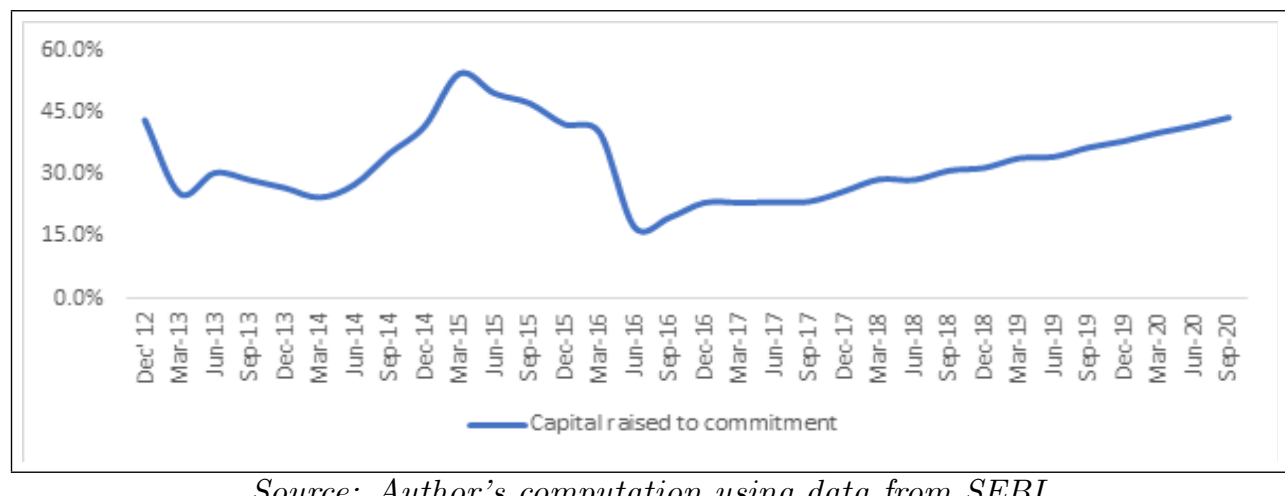

Source: Author's computation using data from SEBI 
Figure 2: Plot of Cumulative Sum of Recursive Residuals (CUSUM) and Cumulative Sum of Squares of Recursive Residuals (CUSUMSQ)

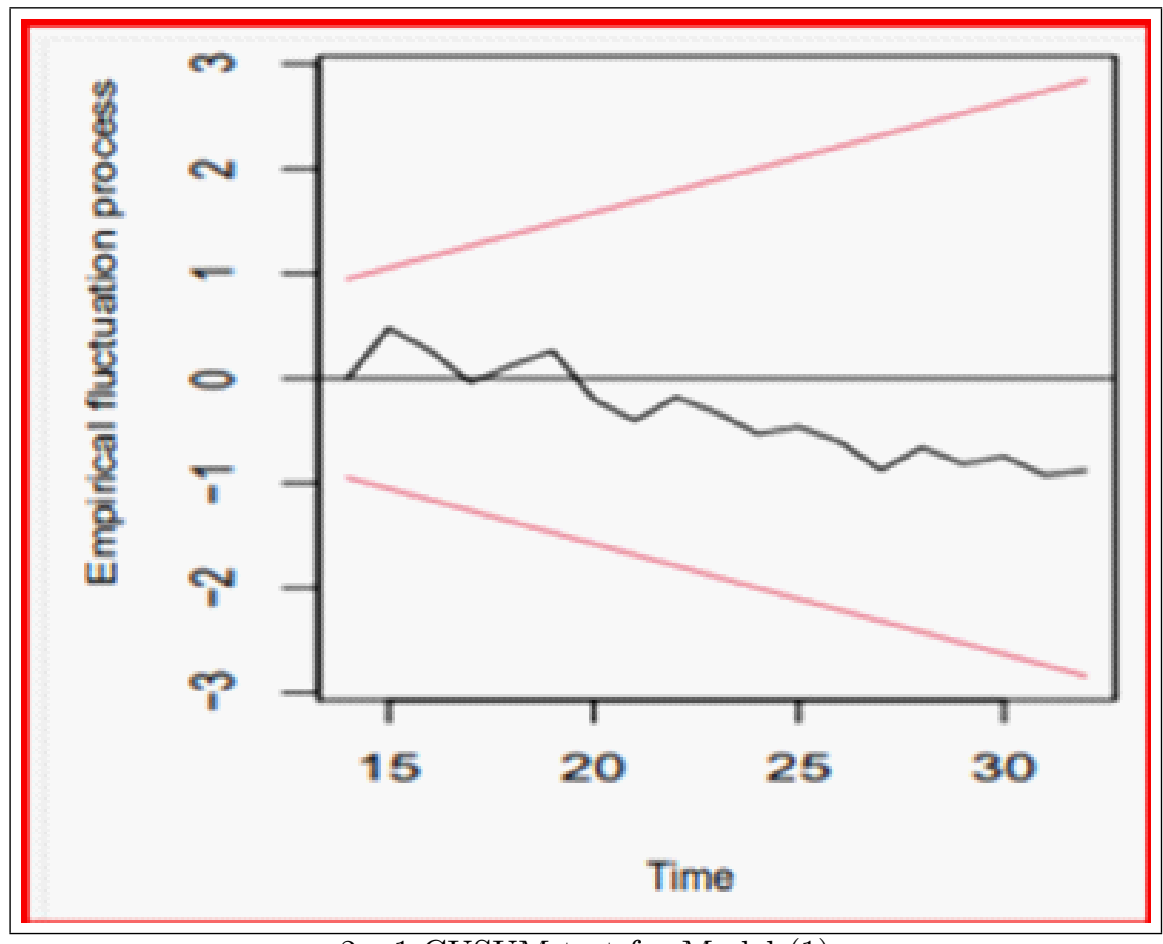

2.a.1 CUSUM test for Model (1)

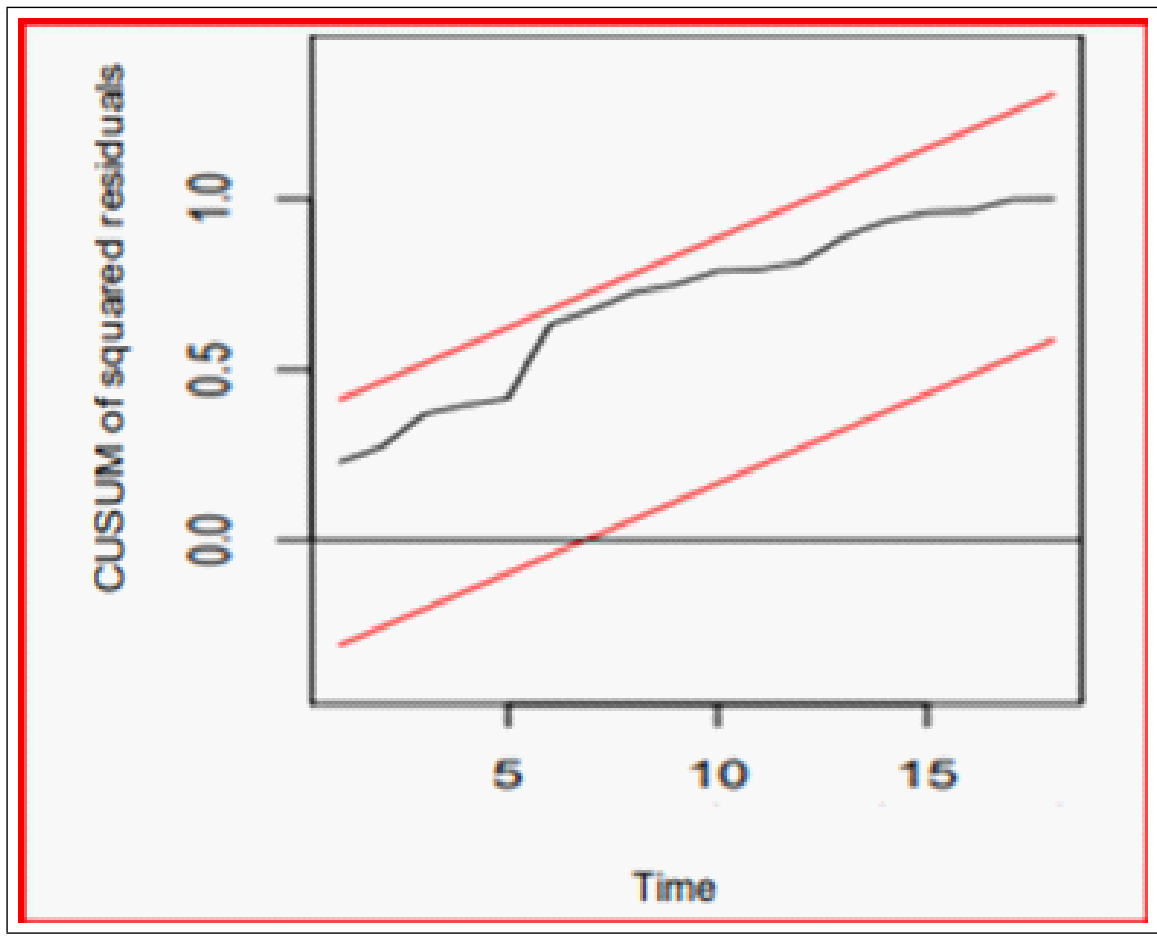

2.a.2 CUSUMSQ test for Model (1) 


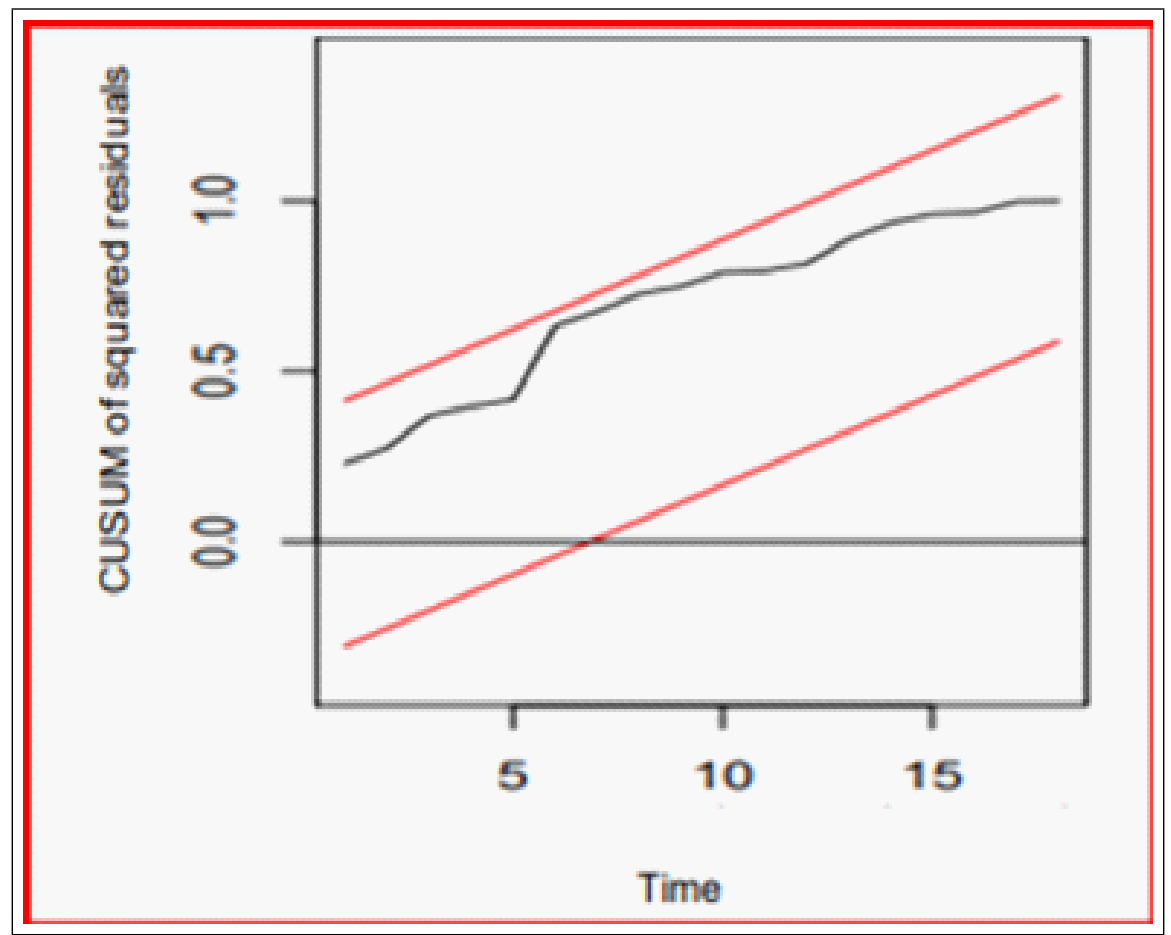

2.b.1 CUSUM test for Model (2)

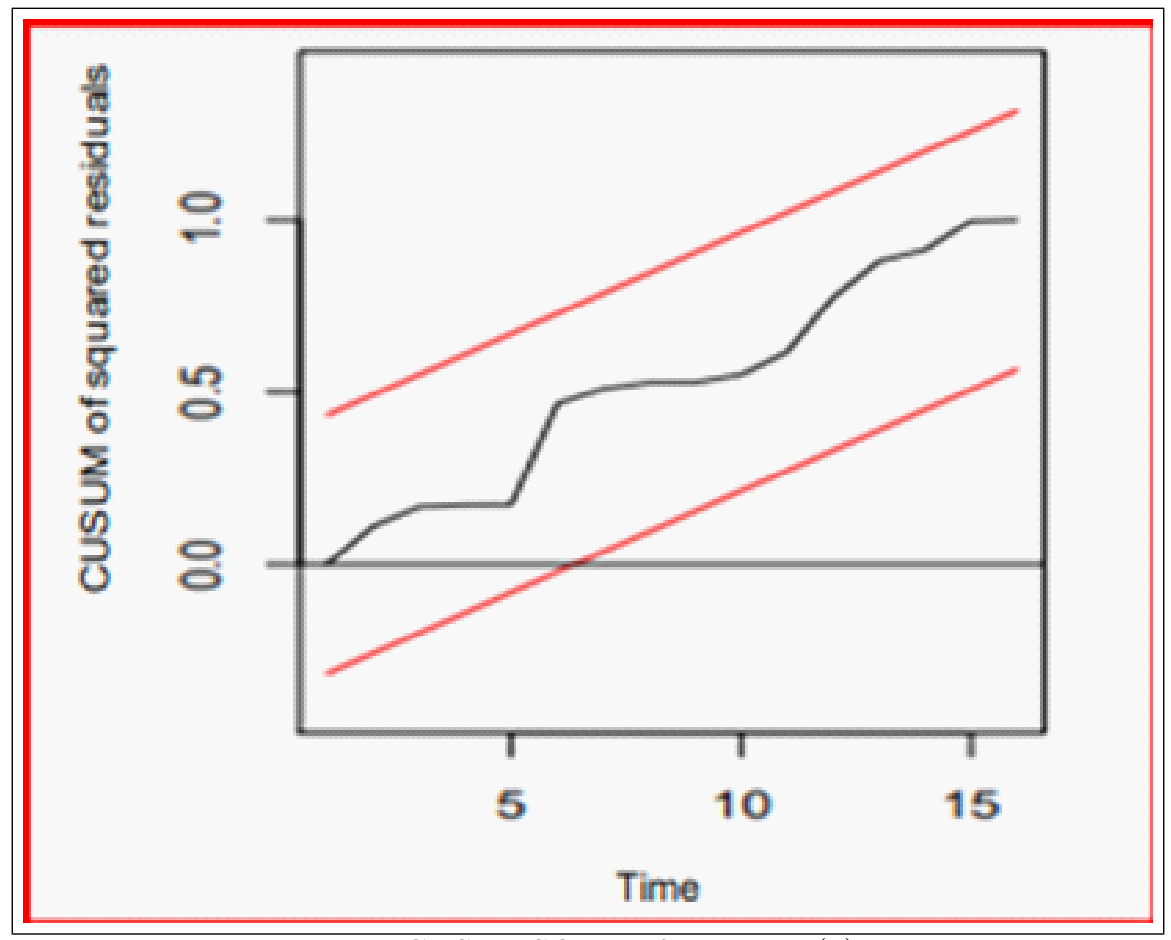

2.b.2 CUSUMSQ test for Model (2)

Note: The straight line in Figure 2 represents critical bounds at 5 percent significance level. 